\title{
In Vitro Evaluation of Bacterial Biocontrol Agents and Botanicals against Alternaria Leaf Spot Caused by Alternaria macrospora in Cotton
}

\author{
B. Mohan Venkata Siva Prasad ${ }^{1}$, S.L. Bhattiprolu' ${ }^{2 *}$, \\ V. Prasanna Kumari ${ }^{1}$ and P. Anil Kumar ${ }^{1}$ \\ ${ }^{1}$ Department of Plant Pathology, Bapatla - 522 101, Andhra Pradesh, India \\ ${ }^{2}$ Regional Agricultural Research Station, Lam, Guntur - 522 034, Andhra Pradesh, India \\ *Corresponding author
}

\section{A B S T R A C T}

Keywords

Alternaria

macrospora, Cotton

leaf spot, Bacterial

biocontrol agents,

Botanicals.

\section{Article Info}

Accepted:

07 September 2017

Available Online:

10 November 2017
Four bacterial biocontrol agents (Pseudomonas fluorescens strain 1, strain 2, strain 3 and Bacillus subtilis strain 1) and six botanicals \{Neem (Azadirachata indica), Lantana (Lantana camera), Calotropis (Calotropis procera), Tulasi (Ocimum sanctum), Onion bulb (Allium cepa), Garlic glove (Allium sativum) \} were evaluated in vitro against Alternaria macrospora causing leaf spot of cotton. All the treatments significantly inhibited mycelial growth of the test fungus over untreated control. Among different bacterial biocontrol agents, B. subtilis strain caused $51.68 \%$ inhibition with $1.73 \mathrm{~cm}$ radial growth of $A$. macrospora followed by $P . f$ strain $1, P . f$ strain 3 and $P . f$ strain 2 with radial growth and inhibition of $A$. macrospora $2.08 \mathrm{~cm}, 41.89 \% ; 2.15 \mathrm{~cm}, 39.94 \%$ and $2.45 \mathrm{~cm}, 31.56 \%$ respectively. Among botanicals, neem leaf extract was superior to other treatments with $2.83 \mathrm{~cm}$ radial growth and $68.52 \%$ inhibition of $A$. macrospora followed by garlic clove with mean radial growth $2.84 \mathrm{~cm}$ and $68.40 \%$ inhibition of A. macrospora compared to control $(9.0 \mathrm{~cm})$.

\section{Introduction}

Cotton (Gossypium spp.) is the most important commercial crops of the world, which belongs to the botanical family Malvaceae. Cotton is referred to as "King of Fibres" and also known as "White Gold". Cotton crop is affected by fungal, bacterial and viral diseases. Among fungal diseases, leaf spot/blight caused by Alternaria macrospora Zimm, is the most commonly occurring disease in Andhra Pradesh. Under congenial conditions the disease causes severe defoliation, cracking and breaking of stems and reduction in boll formation. The disease caused losses to the tune of $38.23 \%$ in
LRA 5166 (Bhattiprolu and Prasada Rao, 2009) and $33.43 \%$ in Jayadhar varieties of cotton (Chattannavar et al., 2010). In recent years, there is a change in trend towards the organic farming to get high quality produce and to protect the environment and public health. Therefore, there is a need and scope for exploiting sources of alternative chemotherapeutants which are reserved in many plant species Based on the importance of Alternaria leaf spot, the present investigation was carried out with a view to find out the efficacy of bacterial biocontrol agents and botanicals against $A$. macrospora. 


\section{Materials and Methods}

\section{Effect of bacterial bio-control agents on radial growth of $A$. macrospora}

Three isolates of Pseudomonas fluorescens, which were native to RARS, Lam, Guntur and one isolate of Bacillus subtilis, native to Agricultural Research Station, Amaravathi were evaluated in vitro for their antagonistic activity against mycelial growth of $A$. macrospora by employing dual culture technique (Dhigra and Sinclair, 1985). Sterilized potato dextrose agar medium, melted and cooled at $45^{\circ} \mathrm{C}$, was poured aseptically into sterilized Petri dishes. Mycelial discs of $5 \mathrm{~mm}$ diameter from the edge of actively growing culture of $A$. macrospora was separately cut with the help of a sterilized cork borer and the disc was placed in the centre of the Petri dishes $(9 \mathrm{~cm}$ diameter) and streaking the bacteria using sterilized inoculation loop on the periphery about one $\mathrm{cm}$ from the edge of Petri dishes on both sides.

The Petri dishes containing potato dextrose agar medium inoculated with the pathogen alone served as control. All the Petri dishes were incubated at room temperature of $25 \pm$ $1^{0} \mathrm{C}$. Ten days after incubation, the colony diameter of the pathogen was measured and the per cent inhibition of A. macrospora was calculated by adopting the following formula given by Vincent (1927).

Per cent inhibition $=$

Radial growth in control (C) - Radial growth in treatment $(\mathrm{T})$

Radial growth in control (C)

The experiment was repeated twice and the mean data on percent inhibition was calculated.

\section{Effect of botanicals on fungal growth}

Six botanicals viz., neem, lantana, calotropis, ocimum, onion, garlic were tested for their efficacy against $A$. macrospora.

\section{Preparation of extracts}

Fresh leaf material of neem, lantana, calotropis and ocimum, onion bulb and garlic cloves were thoroughly cleaned, surface sterilized with ethanol and washed well with sterile water. The plant tissue was ground with sterile water at the rate of $1 \mathrm{ml} / \mathrm{g}$ of plant tissue using sterilized pestle and mortor, and the macerate was filtered through a muslin cloth to get the crude extract.
The extracts of each plant species were tested at 5,10 and 15 per cent concentration against the mycelial growth of $A$. macrospora by poisoned food technique (Nene and Thapliyal, 1993). The radial growth of fungal colony was measured and per cent inhibition of growth over control was calculated (Vincent, 1927).

To the sterilized potato dextrose agar medium, melted and cooled at $45^{\circ} \mathrm{C}$, required quantity of the vacuum filtered crude leaf extract was added so as to get the required concentrations (5,10 and 15 per cent) of the extract in the medium. The molten potato dextrose agar medium containing leaf extracts was stirred well and poured into Petri dishes and allowed to solidify. Mycelium disc of 5 $\mathrm{mm}$ size cut from 10 days old colony of $A$. macrospora was grown on Petri plate containing potato dextrose agar with different leaf extracts at different concentrations. 
Potato dextrose agar medium without any plant extract was inoculated with $A$. macrospora to serve as control. Four replicates were maintained for each leaf extract at each concentration. All the Petri dishes were incubated at room temperature of $25 \pm 1^{0} \mathrm{C}$.

\section{Results and Discussion}

Effect of bacterial bio-control agents on the growth of A. macrospora

All the strains of bacterial biocontrol agents (Pseudomonas fluorescens and Bacillus subtilis) reduced the radial growth of $A$. macrospora compared to control (Table 1).

Among these bacterial biocontrol agents, B.s strain, $P . f$ strain $1, P . f$ strain 3 and $P . f$ strain 2 recorded $1.73 \mathrm{~cm}, 2.08 \mathrm{~cm}, 2.15 \mathrm{~cm}$ and 2.45 $\mathrm{cm}$ radial growth with 51.68\%, 41.89\%, $39.94 \%$ and $31.56 \%$ inhibition respectively (Fig. 1 and Plate 1).

Effect of botanicals on the growth of $A$. macrospora

All the botanicals, at all the concentrations tested, significantly reduced the radial growth of A. macrospora compared to check $(9.00$ $\mathrm{cm}$ ) (Table 2). Among the botanicals, garlic clove and neem leaf extract with mean radial growth of $2.84 \mathrm{~cm}$ and $2.83 \mathrm{~cm}$ respectively, were significantly more effective followed by onion bulb and tulasi leaf with $3.27 \mathrm{~cm}$ and $3.44 \mathrm{~cm}$ mean radial growth respectively. The significantly least effective botanicals, calotropis and lantana recorded mean radial growth of $3.52 \mathrm{~cm}$ and $3.58 \mathrm{~cm}$, respectively (Plate 2).

Fig.1 Effect of bacterial biocontrol agents (Pseudomonas fluorescens and Bacillus subtilis) on the growth of Alternaria macrospora in vitro

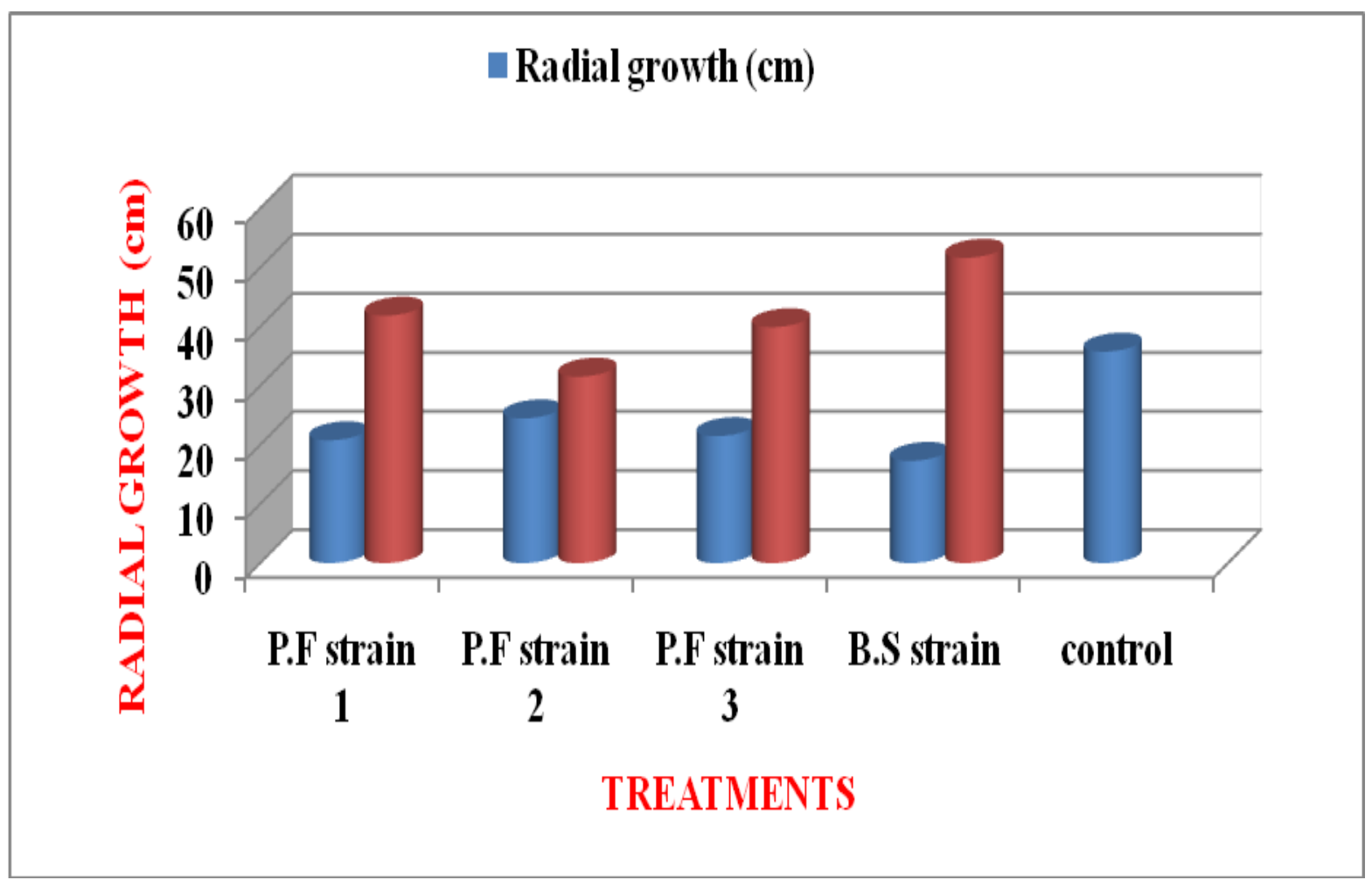


Fig.2 Effect of plant extracts on growth of Alternaria macrospora in vitro

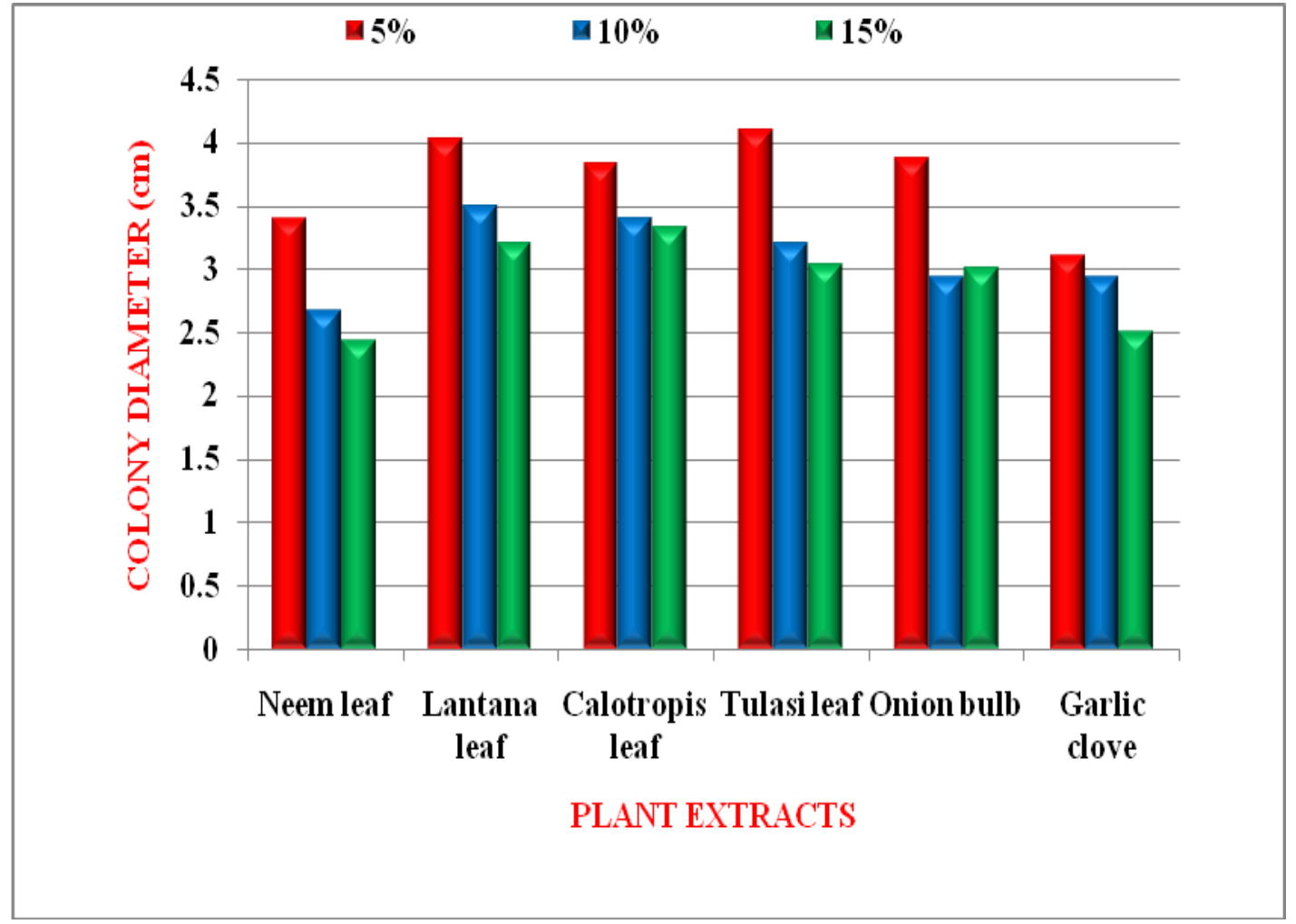

Fig.3 Effect of plant extracts on per cent growth inhibition of Alternaria macrospora in vitro

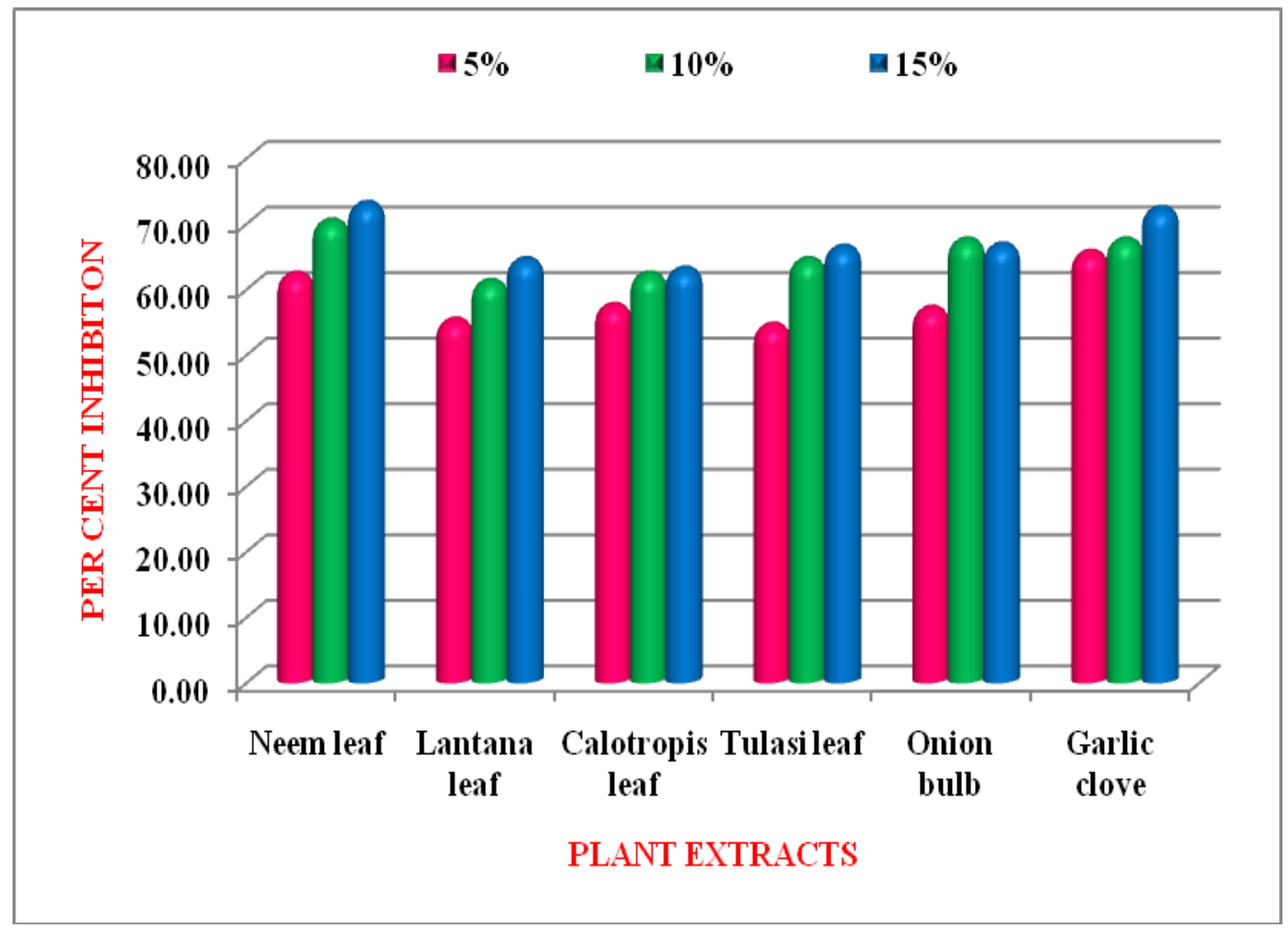


Plate.1 Effect of bacterial biocontrol agents (Pseudomonas fluorescens strains and Bacillus subtilis) on radial growth of Alternaria macrospora
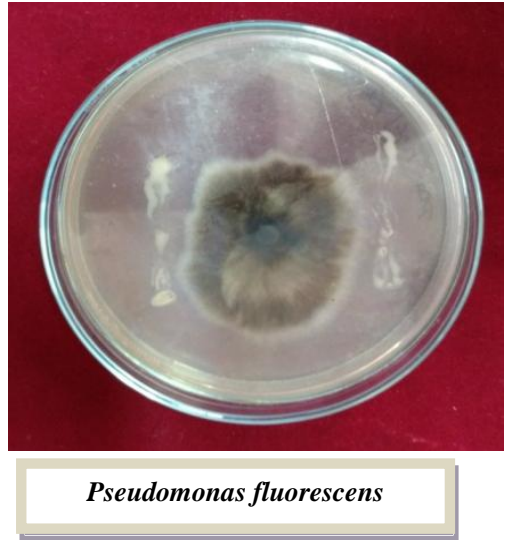

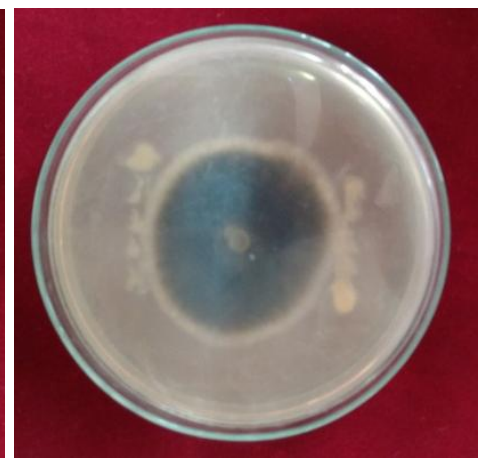

P. fluorescens strain 2

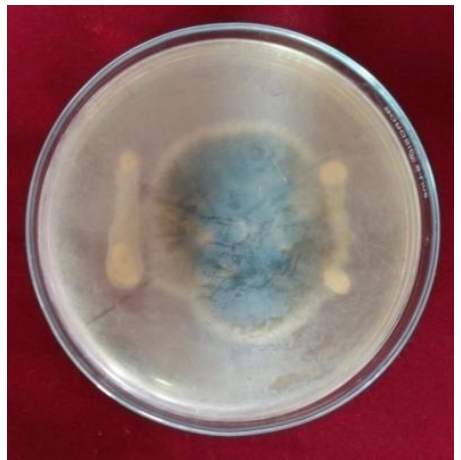

P. fluorescens strain 3

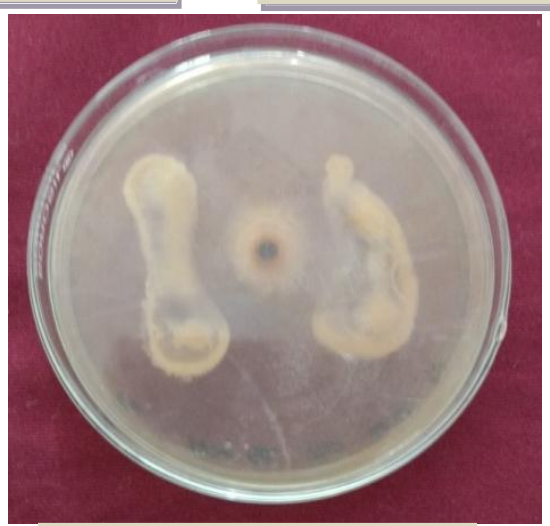

Bacillus subtilis strain 1

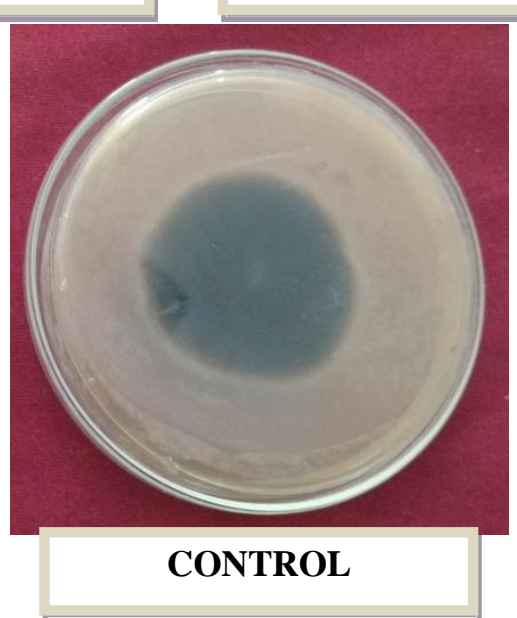

Table.1 Radial growth of Alternaria macrospora dual cultured with bacterial biocontrol agents (Pseudomonas fluorescens and Bacillus subtilis) in vitro

\begin{tabular}{|c|l|c|c|}
\hline S. No. & \multicolumn{1}{|c|}{ Treatment } & Radial growth $(\mathbf{c m})^{*}$ & Inhibition (\%) \\
\hline 1 & $P . f$ strain 1 & $2.08(1.44)^{\mathrm{b}}$ & 41.89 \\
\hline 2 & $P . f$ strain 2 & $2.45(1.57)^{\mathrm{d}}$ & 31.56 \\
\hline 3 & $P . f$ strain 3 & $2.15(1.47)^{\mathrm{cb}}$ & 39.94 \\
\hline 4 & B.s strain & $1.73(1.31)^{\mathrm{a}}$ & 51.68 \\
\hline 5 & Control (A. macrospora) & $3.58(1.89)^{\mathrm{e}}$ & \\
\hline & SEm \pm & 0.02 & \\
\hline & CD $(\mathrm{P} \leq 0.05)$ & 0.05 & \\
\hline & CV $(\%)$ & 2.10 & \\
\hline
\end{tabular}

P.f - Pseudomonas fluorescens, B.s - Bacillus subtilis

* Mean of four replications

Figures in parentheses are square root transformed values

Treatment means with same alphabet do not differ significantly 
Table.2 In vitro evaluation of plant extracts at different concentrations against Alternaria macrospora

\begin{tabular}{|c|c|c|c|c|c|c|c|c|c|}
\hline \multirow{2}{*}{ S. No. } & \multirow{2}{*}{$\begin{array}{c}\text { Botanicals/ } \\
\text { Concentration }\end{array}$} & \multicolumn{3}{|c|}{ Colony diameter $(\mathrm{cm})^{*}$} & \multirow{2}{*}{ Mean } & \multicolumn{3}{|c|}{ Per cent Inhibition } & \multirow{2}{*}{ Mean } \\
\hline & & $5 \%$ & $10 \%$ & $15 \%$ & & $5 \%$ & $10 \%$ & $15 \%$ & \\
\hline 1 & Neem leaf & $3.40(1.84)$ & $2.67(1.63)$ & $2.43(1.56)$ & $2.83(1.68)$ & 62.22 & 70.33 & 73.00 & 68.52 \\
\hline 2 & Lantana leaf & $4.03(2.01)$ & $3.50(1.87)$ & $3.20(1.79)$ & $3.58(1.89)$ & 55.22 & 61.11 & 64.44 & 60.26 \\
\hline 3 & Calotropis leaf & $3.83(1.96)$ & $3.40(1.84)$ & $3.33(1.83)$ & $3.52(1.88)$ & 57.44 & 62.22 & 63.00 & 60.89 \\
\hline 4 & Tulasi leaf & $4.10(2.02)$ & $3.20(1.79)$ & $3.03(1.74)$ & $3.44(1.85)$ & 54.44 & 64.44 & 66.33 & 61.74 \\
\hline 5 & Onion bulb & $3.87(1.97)$ & $2.93(1.71)$ & $3.00(1.73)$ & $3.27(1.80)$ & 57.00 & 67.44 & 66.66 & 63.70 \\
\hline \multirow[t]{7}{*}{6} & Garlic clove & $3.10(1.76)$ & $2.93(1.71)$ & $2.50(1.58)$ & $2.841 .68)$ & 65.55 & 67.44 & 72.22 & 68.40 \\
\hline & Mean & $3.72(1.93)$ & $3.11(1.76)$ & $2.92(1.71)$ & & 58.65 & 65.50 & 67.61 & \\
\hline & Control & \multicolumn{3}{|c|}{$9.00(3.00)$} & \multirow[b]{2}{*}{$\begin{array}{c}\text { Check } v s \\
\text { Others }\end{array}$} & & & & \\
\hline & & Botanical & Concentration & B X C & & & & & \\
\hline & $\mathrm{SEm} \pm$ & 0.01 & 0.01 & 0.02 & 0.02 & & & & \\
\hline & $\mathrm{CD}(\mathrm{P} \leq 0.05)$ & 0.03 & 0.02 & 0.05 & 0.05 & & & & \\
\hline & $\mathrm{CV}(\%)$ & & $1.54 \%$ & & & & & & \\
\hline
\end{tabular}

*Figures in parentheses are square root transformed values 
Plate.2 Effect of plant extracts on radial growth of Alternaria macrospora
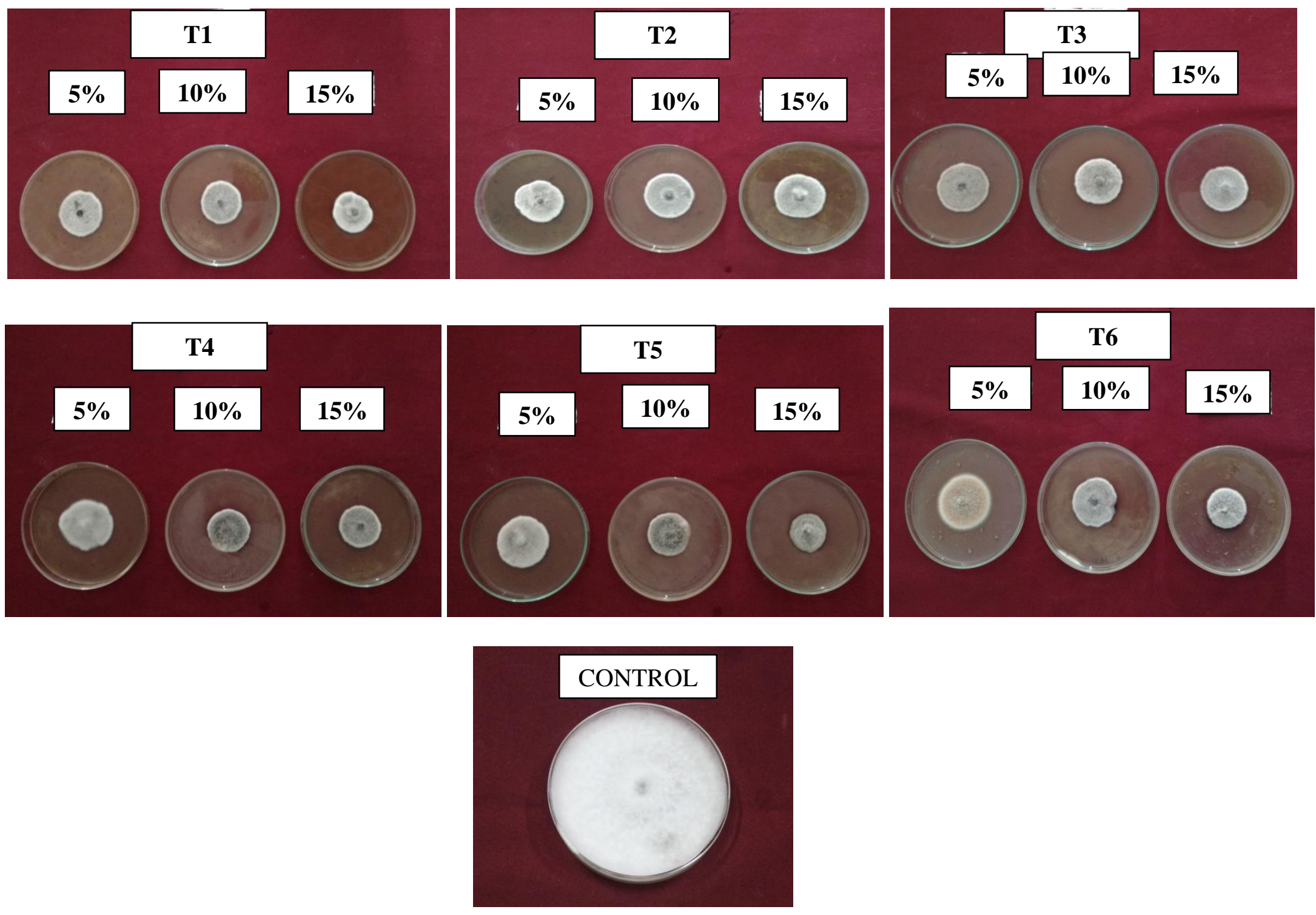
Significant decrease in radial growth with increase in concentration was recorded with all botanicals. Significantly the least radial growth of $A$. macrospora was obtained with $15 \%(2.92 \mathrm{~cm})$ and the highest with $5 \%$ concentration $(3.72 \mathrm{~cm})$. The mean radial growth for each concentration was significantly lesser than that of the next higher concentration (Fig. 2).

Interaction between botanicals and concentrations revealed that inhibition of growth at $5 \%$ concentration of botanicals ranged between $54.44 \%$ in tulasi and $65.55 \%$ in garlic. The next superior botanical, neem recorded $62.22 \%$ inhibition followed by calotropis $(57.44 \%)$, onion bulb $(57.00 \%)$ and lantana $(55.22 \%)$ respectively.

At $10 \%$ concentration of plant extracts inhibition of growth ranged between $61.11 \%$ in lantana and $70.33 \%$ in neem. The next superior botanical, onion bulb and garlic clove recorded $67.44 \%$ inhibition. At $15 \%$ concentration of plant extracts inhibition of growth ranged between $63.0 \%$ in calotropis and $73.00 \%$ in neem. The next superior botanical, garlic clove recorded $72.22 \%$ inhibition (Fig. 3).

Prasad and Naik (2003) reported that most of the plant extracts showed fungicidal activity at higher concentration $(7.5 \%)$ with garlic bulb extract being the most effective causing 90.7 per cent of mycelial growth inhibition followed by Prosopis juliflora leaf extract (79.9\%) against $A$. solani. Ramegouda (2007) reported that among botanicals, garlic bulb extract was effective against A. macrospora under in vitro conditions. Arun Kumar (2008) reported that six botanicals evaluated against A. alternata were found to be effective. NSKE (43.67\%) was significantly superior over all other plant extracts evaluated. The next best treatment was neem leaf extract (15.18\%). Sanjeev et al. (2017) reported that among different botanicals tested onion and garlic extracts showed significant reduction in mycelia growth of $A$. alternata in vitro

The present results suggest utilization of the effective isolates of $B$. subtilis and $P$. fluorescens; and extracts of neem and garlic in the integrated management of Alternaria leaf spot in cotton.

\section{References}

Arun Kumar, G.S. 2008. Studies on leaf blight of chrysanthemum caused by Alternaria alternata (Fr.) Keissler. $M$. Sc. Thesis, University of Agricultural Sciences, Dharwad, Karnataka, India.

Bhattiprolu, S.L. and Prasada Rao, M.P. 2009. Estimation of crop losses due to Alternaria leaf spot in cotton. J. Indian Soc. Cotton Impr., 14 (2): 151-154.

Chattannavar, S.N., Hosagoudar, G.N. and Ashtaputre. S.A. 2010. Crop loss estimation due to foliar diseases in cotton. Karnataka J. Agric. Sci., 23: 559 -601 .

Dhingra, O.D and Sinclair, J.B. 1985. Dual culture technique. Basic Plant Pathology Methods, CRC Press, USA. 355.

Nene, Y.L. and Thapliyal, P.N. 1993. Poison food technique. Fungicides in Plant Disease Control (2 ${ }^{\text {nd }}$ Edition). Oxford and IBH publication, New Delhi, India. 413-415.

Prasad, Y. and Naik, M.K. 2003. Evaluation of genotypes, fungicides and plant extracts against early blight of tomato caused by Alternaria solani. Indian J. Plant Prot., 31 (2): 49-53.

Ramegowda, G. 2007. Disease scenario in $B t$ cotton with special reference to Alternaria leaf spot. M. Sc. Thesis, University of Agricultural Sciences, Dharwad, Karnataka, India.

Sanjeev, P.J., Mesta, R.K., Biradar, I.B., 
Sadanand, K.M. and Ajjappalavar, P.S. 2017. Int. J. Curr. Microbiol App. Sci., 6 (5): 495-504.
Vincent, J.M. 1927. Distortion of fungal hyphae in the presence of certain inhibitors. Nature. 59: 850.

\section{How to cite this article:}

Mohan Venkata Siva Prasad B., S.L. Bhattiprolu, V. Prasanna Kumari and Anil Kumar, P. 2017. In Vitro Evaluation of Bacterial Biocontrol Agents and Botanicals against Alternaria Leaf Spot Caused by Alternaria macrospora in Cotton. Int.J.Curr.Microbiol.App.Sci. 6(11): 750-758. doi: https://doi.org/10.20546/ijcmas.2017.611.088 